Global Energy Policy Center

18 September 2010

Issue Brief 10-08

\title{
Kyoto's Climate Game and How to Fix It
}

\author{
By Peter Cramton and Steven Stoft*
}

\begin{abstract}
The Kyoto summit initiated an international game of cap and trade. Unlike a national cap-andtrade policy, the essence of this game is the self-selection of national emission targets. This is like the standard global public-goods game except that targets are met in the context of a global carbon market. This changes the outcome of the notoriously uncooperative public-goods game.

The equilibrium of the new game may increase or decrease total abatement. If it increases abatement, the resulting carbon price will be no greater than the average public-goods price. Typically, high abaters in the public goods game will target more abatement in the cap-and-trade game, while low abaters will target less.

Given such a dismal outcome the Kyoto game should be changed to the global price-target game. In the same setting where cap-and-trade reduces abatement, this game induces optimal abatement. But, realistically, it must include a Green Fund whose strength is linked to the price target. This will induce poor countries to favor as high a price target as rich countries, reversing the polarizing and anti-cooperative tendencies of cap and trade.
\end{abstract}

The Kyoto climate summit began stage one of the international cap-and-trade game. The outcome was not as intended. Instead we have "hot air" for the former Soviet Union, business-as-usual caps for the poor, and binding caps for some cooperative countries. The U.S. and Australia refused to play. Although unexpected, these outcomes loosely reflect the game's non-cooperative outcome (Nash equilibrium).

As stage one drags on, national behaviors have continued to follow a key prediction of game theory-polarization of abatement efforts between developed and developing countries. The net result has been little progress and much acrimony. While these outcomes were anticipated by some, the rigorous analysis of the international cap-and-trade game deserves special attention. Published in 2003 by Carsten Helm and expanded and clarified by Holtsmark and Sommervoll in 2008, it has been ignored too long.

\section{INTERNATIONAL CAP AND TRADE DIFFERS FROM NATIONAL PROGRAMS}

Originally, cap and trade was designed in the context of a national government that would impose the over-all cap. Its purpose was to control emissions with market-based efficiency. But with no international government, the first stage of the international game requires each country to voluntarily select an abatement target. As should now be clear, these targets are chosen largely according to selfinterest.

\footnotetext{
* Peter Cramton is Professor of Economics at the University of Maryland and an expert on market design; Steven Stoft is Director of the Global Energy Policy Center and the author of Carbonomics. Their research on climate policy can be found at www.global-energy.org.
} 
The crucial first stage of the international game parallels the classic public-goods game faced by the world before Kyoto. In that game, countries voluntarily select a domestic abatement level. But acting alone, a country looks to its self-interest and ignores most of the global damage it causes. Theory, observation, and experiments all confirm that such games produce even less cooperation than the prisoners' dilemma. In the latter game, cooperation increases with repetition and experience while in the public-goods game, players become less cooperative as they gain experience.

But the public-goods equilibrium predicts that there will be some abatement. If a ton of emissions does $\$ 100$ of damage globally, but only $\$ 5$ of damage to the country in question, that country will be willing to spend up to $\$ 5$ per ton to abate emissions. That determines the non-cooperative equilibrium - the Nash equilibrium - of the public-goods game. In such an equilibrium, no country can improve its lot by changing its strategy. Because countries are so small compared to the global problem, the public-goods equilibrium is disastrously uncooperative.

To remedy this problem, we need to change the public-goods game to make countries more interdependent. Adding Kyoto's cap-and-trade rules does just that. Under those rules, a country does not choose its own abatement level, rather it chooses an abatement "target," which can be met with either domestic abatement or purchases of abatement credits in a global carbon market. The global market coordinates a form of cooperation that minimizes the cost of abatement.

Finding the cap-and-trade equilibrium is mathematically a bit more difficult than finding the publicgoods equilibrium, but conceptually it is the same. An analysis of the equilibrium yields three results. ${ }^{1}$

- A low price. If cap-and-trade helps the climate, then the global price of carbon will be less than the unweighted country-average price of carbon (the marginal cost of abatement) in the publicgoods game.

- Polarization. Countries with high abatement levels in the public-goods game will target more abatement under cap-and-trade, and countries with low abatement levels will target less.

- Ambiguity. Adding cap-and-trade rules to the international public goods game can either increase or decrease total global abatement relative to no policy at all (Helm 2003).

A simple example will help clarify all three results. Suppose there were four large countries gaining a $\$ 20$ climate benefit per ton of abatement, and four small countries gaining a $\$ 5$ benefit per ton. In the public-goods game, they would set domestic carbon prices (with a cap or a tax) to $\$ 20$ and $\$ 5$ per ton respectively. But, under cap and trade, the global price of carbon would be $\$ 12.50$ per ton-a low price, compared with the optimal price of $\$ 100$ per ton.

The large countries would see that they can purchase abatement at this low price instead of their previous domestic marginal cost of $\$ 20$ and they would target more abatement under cap and trade than under no global policy. The small countries, however, would see the global price as higher than their private climate benefit of $\$ 5$ and they would target less abatement. Together, these responses comprise what we call polarization.

But what is the net effect on total abatement? If the countries are identical except for size, total abatement will decrease $26 \%$, while it should optimally increase almost six fold. Decreasing abatement is a general result proved by Holtsmark and Sommervoll (2008) for countries that are the same except for size. In this example, large countries target 2.5 times more abatement than in the public-goods game, but small countries target a negative amount of abatement. Total abatement declines.

Cap and trade can increase abatement if the small countries, in spite of their small size, have larger abatement opportunities than the large countries. Hence the total abatement outcome is ambiguous.

Of course, in practice, countries differ for more reasons than size. But it is still true that those inclined to abate most without a global policy will target more abatement under cap and trade, and 
those inclined to abate least will target less. Cap and trade still causes polarization. The downside of polarization still drags down the global price, and the effect on abatement is still ambiguous.

It has often been asserted that Europe is more willing to accept a high target because it can meet that target more cheaply with credits purchased in the global carbon market. This is one side of polarization. The Waxman-Markey bill, passed by the U.S. House, allowed the purchase of two billion tons of international credits per year in order to hold down the cost of meeting the U.S. abatement target. This too is polarization, and so is Russia's demand for "hot air" and the demands of the developing countries to be allowed to sell U.N. Certified Emission Reductions for any "additional" abatement.

But the outcome of the cap-and-trade game has been worse than the equilibrium predicts. The developed countries dislike the Nash equilibrium and try to argue the developing countries out of it, while the developing countries insist on it. This has prevented any agreement of global significance and led to an acrimonious negotiating climate.

\section{FROM CAPS TO COOPERATION}

Although cap and trade improves the efficiency of the abatement that does occur, it makes the choice of how much to abate even less cooperative. To fix this problem, nations could collectively choose a single global cap. In fact, in the example above a global-cap game could lead to optimal abatement. With individual caps, a country can only tighten the global cap by tightening its own cap. So it must pay the full cost of its tightening of the global cap. But if responsibility for a global cap is shared in proportion to country size, a country will raise the global cap and pay only its share of the cost.

Why has this possibility been ignored? Because, there is no agreement on how to share a global cap in proportion to size. In fact there is not even a proposal worth discussing. As with a national cap, obligations would be apportioned by the allocation of emission permits. If these are allocated by GDP, the poor countries will object, and if they are allocated by population, the rich countries will object.

A different global target is required-one that provides the same global abatement efficiency, but that facilitates an agreement on how national targets should reflect a global target. Price is such a target. In fact the advocates of cap and trade already agree that equal national carbon prices are one of the greatest benefits of cap and trade. And economists agree that if equal prices create equity concerns, the answer is equity transfers and not price distortions. Unlike the concept of size-proportional caps, which leads to bitter disputes, the concept of equal carbon prices is a focal point of near universal agreement.

\section{PRICING DOES NOT MEAN TAXING}

Before describing the price-target game, it's best to clear up a persistent confusion. At the national level, pricing can mean either cap-and-trade or a carbon tax-both put a price on carbon (Cooper 2008). Internationally, pricing is not an abatement policy but only a commitment to adopt some policy that raises the cost of emissions. This avoids forcing Europe to abandon cap-and-trade and avoids forcing India and China to adopt it.

But it would be difficult to meet a rigid price commitment with cap and trade. It can also be difficult to meet a rigid cap (as opposed to a target), which is why the Kyoto approach is actually "abatement targets and trade." Countries can miss their abatement target domestically but make it up in the international market. A price commitment needs that same flexibility, and we propose what amounts to "price targets and trade." There would be an international market in carbon-pricing credits. Flexible global carbon pricing has other advantages as well (Cramton and Stoft 2009), but for now it is enough to note that, under it, countries can easily adopt cap and trade or any mix of pricing measures. 


\section{THE PRICE TARGET GAME}

Having checked international cap and trade with game theory, it's only fair to apply the same test to the price-target game. Doing so requires a simple version of the game. Instead of setting an abatement target, each country makes a suggestion for how high the common price-target should be. In this simple version of the game, the global target is set equal to the lowest suggestion. We can test this game on the same set of eight countries used in the cap-and-trade example.

In stark contrast to cap and trade, the Nash equilibrium of this simple price-target game selects the optimal climate policy, a $\$ 100$-per-ton price target (instead of $\$ 12.50$ under cap and trade). This is because, just as with a single global cap, countries see that they receive much greater benefit from raising a collective target than from raising a private target, yet either way their cost is the same. In both games the Nash equilibrium depends on the rules of the game being enforced. For cap and trade this means countries must enforce the domestic permit requirement. In the price-target game, countries must implement the global price (though they will never have to enforce a higher price than they suggested for the global target).

The price-target game changes the incentives of countries by assuring them that if their suggestion increases their own effort (price) it will also increase the effort of all other countries.

But the simple price-target game suffers from two problems. Some countries, such as oil exporters, do not want the world to adopt a strong climate policy, and some poor countries do, but will want help with the cost of abatement. The first problem can be solved by excluding the suggestions of some percentage of countries with low price-target suggestions.

Poor countries require a different approach. They have contributed little to the climate problem, care less about problems fifty years hence, and find it harder to shoulder the burden of abatement. Hence, they will suggest a low carbon price unless they receive some help with abatement costs, as they now receive from the U.N.'s program of Certified Emission Reductions (CERs). While this program has been accused of discouraging international abatement commitments, global pricing would be accompanied by a Green Fund that encourages commitment and a higher global price target.

\section{THE GREEN-FUND GAME}

Countries with above-average per-capita emissions would contribute to the Green Fund, and countries with below-average emissions would receive funding. Most importantly, the payments are proportional to the global price target. Because of this, poor countries will suggest a higher value for the price target. This allows the Green-Fund game to produce highly cooperative solutions, even when poor countries are inherently less willing to pay for abatement.

We model this inherent difference by assuming that poor countries see abatement costs (and Green-Fund payments) as magnified in inverse proportion to their per-capita emissions. In other words, poor countries see present monetary flows as magnified relative to future climate benefit. Consequently they want lower abatement costs and would suggest a lower price target, were it not for wanting a higher Green-Fund payment. 
Table 1. The Nash Equilibrium of a Green-Fund, Price-Target Game

\begin{tabular}{|c|c|c|c|c|c|c|c|c|}
\hline & Population & $\begin{array}{l}\text { Emissions } \\
\text { per Capita }\end{array}$ & $\begin{array}{c}\text { Suggested } \\
\text { Price } \\
\text { Target }\end{array}$ & $\begin{array}{l}\text { Global } \\
\text { Price } \\
\text { Target }\end{array}$ & Abatement & $\begin{array}{l}\text { Climate } \\
\text { Benefit }\end{array}$ & $\begin{array}{c}\text { Abate } \\
\text { Cost }\end{array}$ & $\begin{array}{l}\text { Green } \\
\text { Fund }\end{array}$ \\
\hline Country & billions & tons & $\$ /$ ton & $\$ /$ ton & $\%$ of optimal & \multicolumn{3}{|c|}{ billion dollars/year } \\
\hline U.S. & 0.3 & 18 & $\$ 26.04$ & \multirow{3}{*}{$\$ 26.04$} & $87 \%$ & $\$ 28$ & $-\$ 12$ & $-\$ 4$ \\
\hline China & 1.2 & 5 & $\$ 30.00$ & & $87 \%$ & $\$ 31$ & $-\$ 14$ & $\$ 0$ \\
\hline India & 1.0 & 1.1 & $\$ 26.04$ & & $87 \%$ & $\$ 6$ & $-\$ 2$ & $\$ 4$ \\
\hline
\end{tabular}

The Green-Fund game reported in Table 1 was constructed so that, if poor countries (India) perceived abatement costs in the same way as rich countries, the optimal outcome would be a \$30-perton global price target and 20 percent abatement. This is intended to represent a near-term policy. Notice that because the Green-Fund has been properly linked to the target price, India and the United States suggest exactly the same global target price, which is 87 percent as high as the optimal target, and this induces 87 percent of the optimal abatement. Moreover, in spite of paying India double the cost of its abatement policy, the Green Fund charge is less than \$1 per ton. That comes to 3.4 cents per person per day in the United States.

The Green-Fund game, like cap and trade, assures that abatement occurs at least cost, but in addition, elicits far more cooperation-a level of abatement much closer to the social optimal. It also provides an excellent lever for encouraging price compliance among low-emission countries. And because the Green Fund is coupled to emissions, it serves as an additional incentive for non-price abatement policies.

\section{A TREATY ON HOW TO AGREE}

A constitution does not specify tax rates, rather it tells how to pass a tax law. This approach is no accident. It is far easier to agree on how to pass a law than to agree on a law without a legislative process. The constitution makes it easier to subsequently pass laws. Climate negotiations have put the cart before the horse and attempted to nail down numbers -7 percent below the 1990 level, 2 degrees, 20 percent by 2020 - without first agreeing on an effective agreement process.

Fortunately, the Green-Fund game lends itself to a constitutional approach. A treaty should, in essence, specify the rules of the Green-Fund game. Signing the treaty would give a country the right to help decide the global price target. When enough have signed, the game would begin. To see how this could work consider a treaty that specifies the following.

1. The voting rule for choosing the Green-Fund parameter, $G$.

2. The voting rule for choosing the price target $P^{T}$, given $G$.

3. A flexible compliance rule including a global market for carbon-pricing credits.

4. The voting rules for price escalation, enforcement mechanisms, and updating.

The Green-Fund parameter, linking payment to the price target, presents a challenge because highemission countries want a low value, and low-emission countries want a high value. However, it is not difficult to specify a voting rule that produces a good outcome by giving most influence to countries with near-average per-capita emissions. Attempting to negotiate $G$ without rules would lead to endless bickering. We have already mentioned a voting rule for $P^{T}$, and this can easily be improved. The general 
voting rule (4) will require assigning weights to the participants. This will be contentious, but in 1974 such a scheme was agreed on in a matter of months when the International Energy Agency was formed.

The greatest remaining concern may be enforcement. Why wouldn't a country sign the treaty, suggest a high value for $P^{T}$, and then renege? Consider the simple price-target game discussed first. It could suffer the same fate. But what if the price-target held for only one year and then was reset by the same voting rule. And what if a country's suggested price was automatically set to its actual carbon price over the previous year, if it was not in compliance? This simple change to the rules makes the repeated price-target game self-enforcing, because countries really do want a cooperative outcome, even if they have to cooperate themselves. In fact this is equivalent to the famous tit-for-tat strategy that can bring cooperation to a repeated prisoners' dilemma.

But this is not the only way to enforce the cooperative outcome. As we have seen, the poorest countries will cooperate because it is profitable. The threat of trade sanctions could be used to enforce compliance by richer countries. And there is always concern for international reputation and the implicit danger that reneging will unravel the treaty.

\section{NO 50-YEAR GUARANTEE}

A global pricing treaty of this sort will fail to lock in the antidote to climate change for the next 50 or 100 years. In fact it will fail to lock in any policy at all. Neither does the constitution of any country or the bylaws of any corporation lock in tax rates or investment plans. The treaty is not designed to produce a specific result but to maximize the efficacy of whatever political will exists. Cultivating a more robust political will is not the responsibility of a treaty. The purpose of voting rules is not to make the electorate wise.

What we need now and for the future is a structure that encourages cooperation and produces the strongest and most efficient possible outcome given the global determination to act. Without a vehicle for cooperative action, proclamations limiting future emissions and temperatures will only lull us into a false sense of accomplishment.

\section{NOTES}

\footnotetext{
${ }^{1}$ For details and derivations of the results see Cramton and Stoft (2010b) and http://www.global-energy.org/lib.
}

\section{REFERENCES AND FURTHER READING}

Carbone, Jared C., Carsten Helm, and Thomas F. Rutherford (2009) "The Case for International Emission Trade in the Absence of Cooperative Climate Policy," Journal of Environmental Economics and Management, $58,266-280$.

Cooper, Richard N. (2008) "The Case for Charges on Greenhouse Gas Emissions," The Harvard Project on International Climate Agreements, Discussion Paper 08-10.

Cramton, Peter and Steven Stoft (2009) "Global Carbon Pricing: A Better Climate Commitment," Global Energy Policy Center Research Paper, 09-06. Available at: www.global-energy.org/lib/.

Cramton, Peter and Steven Stoft (2010a) "Price Is a Better Climate Commitment," The Economists' Voice, 7:1, Article 3. Available at: www.bepress.com/ev/vol7/iss1/art3.

Cramton, Peter and Steven Stoft (2010b) "International Climate Games: From Caps to Cooperation," Global Energy Policy Center Research Paper, 10-07. Available at: www.global-energy.org/lib/. 
Godal, Odd and Bjart J. Holtsmark (2010) "International Emissions Trading and Endogenous Taxes," Discussion Papers 626, Research Department of Statistics Norway.

Helm, Carsten (2003) "International Emissions Trading with Endogenous Allowance Choices," Journal of Public Economics, 87, 2737-2747.

Holtsmark, Bjart J. and Dag Einar Sommervoll (2008) "International Emissions Trading in a Non-cooperative Equilibrium," Discussion Papers 542, Research Department of Statistics Norway.

Stiglitz, Joseph E. (2006) “A New Agenda for Global Warming," The Economists' Voice 3(7): Art. 3. Available at: www.bepress.com/ev/vol3/iss7/art3. 